\title{
The black goby Gobius niger as a potential paratenic host for the parasitic nematode Anguillicola crassus in a thermal effluent of the Baltic
}

\author{
Johan Höglund ${ }^{1}$, Krista Thomas ${ }^{2}$ \\ ${ }^{1}$ The National Veterinary Institute, Box 7073, S-75007 Uppsala, Sweden \\ ${ }^{2}$ Laboratory for Ecology and Aquaculture, Naamsesstraat 59, B-3000 Leuven, Belgium
}

\begin{abstract}
Species of fish preyed upon by the European eel Anguillicola anguilla were examined for infective larvae of the swimbladder nematode. Anguillicola crassus, in an area of the Baltic receiving thermal discharges from the Oskarshamn nuclear power station in Sweden. We found that the main paratenic hosts for $A$. crassus were 2 benthic species: the black goby Gobius niger and ruffe Gymnocephalus cernua. This finding is somewhat at variance with findings from Central Europe. Larvae and adult parasites recovered from eels fed with larvae from the black goby were scrutinized, using scanning electron microscopy, and their species identified on a morphological basis. A positive relationship between larval transmission into eels and surrounding water temperature was found. Parasite establishment and development in the eel were also demonstrated to be favoured at a moderately high water temperature. It is concluded that in addition to freshwater fish species, those of marine origin may also be important vectors for A. crassus in coastal waters.
\end{abstract}

\section{INTRODUCTION}

In the past few years, concern about the parasitic nematode Anguillicola crassus has increased. The parasite was introduced to stocks of the European eel Anguilla anguilla in the beginning of the 1980's in conjunction with intercontinental transports of live Japanese eels Anguilla japonica for consumption and stocking in aquaculture (Neumann 1985, Peters \& Hartmann 1986). The haematophageous adult parasites, dwelling in the swimbladder lumen of the eels, cause serious pathology that is feared to interfere with the Atlantic migration of the eels to the spawning grounds in the Sargasso Sea (Ghittino et al. 1989, van Banning \& Haenen 1989). Compared to the Japanese eel, the European eel is highly susceptible to infection (Egusa 1979). Consequently, anguillicolosis is believed to constitute a major threat to the European eel and it has been suggested that the decrease in yearly catches of glass eels drifting to the European continent might be due in part to the introduction of the parasite (EIFAC, Working Party on Eel, Dublin, Ireland, 20-25 May 1991).
Since the first reports of Anguillicola crassus in Europe, the parasite spread has now been reported in Austria (Belpaire et al. 1989a), Belgium (De Charleroy et al. 1987), Denmark (Køie 1988), England (Kennedy \& Fitch 1990), Estonia (Kangur pers. comm.), France (Dupont \& Petters 1988), Germany (Koops \& Hartmann 1989), Greece (Belpaire et al. 1989a, b), Hungary (Székely et al. 1991), Italy (Canestri-Trotti 1987), the Netherlands (Dekker \& van Willigen 1989), Poland (Hellström et al. 1988), Portugal (Domingos pers. comm.), Spain (Belpaire et al. 1989a) and Yugoslavia (Bosnakovski pers. comm.). A. crassus was recently detected in Sweden for the first time (Hellström et al. 1988). In Sweden, however, the parasite has not yet spread to eel stocks in inland freshwaters, as it has in Central European countries (Höglund et al. in press). On the other hand, infected eels have been found along the coast with a concentration in 2 Baltic areas that receive thermal discharge from nuclear power stations (Höglund et al. in press).

Copepods and ostracods act as the intermediate hosts in the life-cycle of Anguillicola crassus (Petter et al. 1989, 1990, Thomas \& Ollevier 1989, De Charleroy 
et al. 1990b). However, it has recently been demonstrated that small freshwater fish also serve as paratenic hosts (De Charleroy et al. 1990b, Haenen \& van Banning 1991). In the present study, various fish species from the most heavily infected site in Sweden, a thermal discharge area off the Baltic coast, were examined for the presence of infective $L_{3}$-larvae of $A$. crassus. The larvae obtained were compared with a Belgian source of larvae from experimentally infected carp, Cyprinus carpio. In addition, the influence of the ambient water temperature on larval transmission and subsequent development was investigated by feeding eels with $\mathrm{L}_{3}$-larvae from the black goby on an experimental basis.

\section{MATERIAL AND METHODS}

Sampling area. The Oskarshamn nuclear power station, consisting of 3 reactors, is located on the Baltic coast of Sweden $20 \mathrm{~km}$ NNE of Oskarshamn. The cooling water for 2 reactors is taken in from the surface at a point slightly to the south of the power station, whereas the cooling water for the third reactor is taken in from the bottom at an $18 \mathrm{~m}$ deep intake east of the power station. All cooling water is taken through tunnels to Hamnefjärden, a $0.17 \mathrm{~km}^{2}$ bay 2 to $5 \mathrm{~m}$ deep. Hamnefjärden is currently the most heavily infected area in Sweden; about $60 \%$ of its eel population is infected. The only link with the surrounding water is a $50 \mathrm{~m}$ wide and $3 \mathrm{~m}$ deep sound, where the current flows at about $1 \mathrm{~m}^{-1} \mathrm{~s}$ and the excess temperature reaches about $10^{\circ} \mathrm{C}$ when the power station is at full capacity. The inner part of Hamnefjärden is a brackish water (salinity $7 \%$ ) area with weak currents. Fish species present are the black goby Gobius niger, bleak Alburnus alburnus, European eel Anguilla anguilla, nine-spined stickleback Pungitus pungnius, perch Perca fluviatilis, pike Esox lucius, roach Rutilus rutilus, rudd Scardinius erythrophthalmus, ruffe Gymnocephalus cernua, silver bream Blicca bjoerkna, and three-spined stickleback Gasterosteus aculeatus. In addition herring Clupea harengus are attracted by the warm water during their spawning period.

Sampling of fish and parasites. The fish were captured by hook and line and/or dip- and fyke nets in October 1990 and March 1991. Thereafter the fish were frozen until they were examined. Upon examination, the fish were thawed and their internal organs were dissected, pressed between 2 glass plates and examined for parasites using a stereomicroscope $(50 \times)$ with transparent light.

Feeding experiment. In the feeding experiment, 2 groups of eels, mean weight $45.3 \mathrm{~g}( \pm 1.6 \mathrm{SD})$, from an uninfected culture system (Scandinavian Silver Eel AB,
Hälsingborg, Sweden) were randomly chosen from a supply tank at the Veterinary Institute in Uppsala. One group was kept at $10^{\circ} \mathrm{C}$ and the other at $20^{\circ} \mathrm{C}$ in $30 \mathrm{l}$ tanks containing aerated water recirculating through an Eheim filter. The same number of $L_{3}$-larvae from naturally infected black gobies from Hamnefjärden were fed to each fish in accordance with the procedure described by De Charleroy et al. (1990a). The gobies were dissected in $0.01 \mathrm{M}$ PBS, pH 7.4 and the internal organs were left overnight at room temperature. Larvae obtained were extracted with a fine pipette and portioned out in groups of 40 in a Nunc 24-well culture plate containing the same buffer. Thereafter the larvae in each well were pipetted into a $100 \mathrm{ml}$ haematocrit tube connected to a syringe. The eels were anaesthetized in Hypnodil $\left(0.1 \mathrm{ml} \mathrm{l}^{-1}\right.$ water), the larvae were orally administered to them, and the eels were returned to the tanks. After $8 \mathrm{wk}$ the eels were killed and their swimbladder wails and lumens were examined for parasites as described above. Parasites recovered were fixed in a mixture of $1.5 \%$ glutaraldehyde and $1.5 \%$ paraformaldehyde in $0.1 \mathrm{M}$ phosphate buffer ( $\mathrm{pH}$ 7.4). Thereafter the developmental stage and sex of the adult parasites were determined.

Preparation for SEM. Adult parasites from the infected eels and $\mathrm{L}_{3}$-larvae obtained from naturally infected black gobies and from carp infected with a Belgian source of Anguillicola crassus were obtained as described above. The parasites were fixed as above for at least $24 \mathrm{~h}$ and were then post-fixed in cold $\left(4{ }^{\circ} \mathrm{C}\right)$ phosphate buffered $1 \% \mathrm{OsO}_{4}$ for $1 \mathrm{~h}$, rinsed and dehydrated in graded concentrations of ethanol. The ethanol was thereafter gradually replaced with filtered Freon TF and the specimens were critical-point dried, using $\mathrm{CO}_{2}$ as the transitional fluid. The dried specimens were mounted on stubs with double-stick tape, coated with gold-palladium and examined at $10 \mathrm{kV}$ in a JEOL JSM-820 electron SEM microscope.

\section{RESULTS}

\section{Prevalence and abundance of infection in the wild}

The black goby and ruffe were the only heavily infected species (Table 1). In both species, larvae were only found in the walls of the swimbladder and in the intestinal tract. There was a positive correlation between fish length and parasite number (black goby: $\mathrm{r}=0.64, \mathrm{n}=25, \mathrm{p}<0.01$; ruffe: $\mathrm{r}=0.43, \mathrm{n}=14, \mathrm{p}<$ $0.01)$. However, the number of dead larvae encapsulated by a host reaction appeared to be higher in the ruffe. Larvae were only occasionally found in bleak and perch, whereas herring, roach, rudd and the sticklebacks were all uninfected (Table 1). 
Table 1. Anguillicola crassus. Prevalence and abundance of $\mathrm{L}_{3}$-larvae of parasite in different fish species from the heated area outside the Oskarshamn nuclear power station off the Baltic coast in Sweden in October 1990 and March 1991

\begin{tabular}{|c|c|c|c|c|c|c|}
\hline Fish species & Date & $\mathrm{n}$ & $\begin{array}{l}\text { Mean length } \\
(\mathrm{mm})\end{array}$ & $\begin{array}{c}\text { Prevalence } \\
(\%)\end{array}$ & $\begin{array}{c}\text { Abundance } \\
\left(\text { mean no. } \text { fish }^{-1}\right)\end{array}$ & $\begin{array}{c}\text { Max. no. of } \\
\text { larvae }\end{array}$ \\
\hline Black goby & Mar & 25 & 66 & 96 & 13 & 43 \\
\hline \multirow[t]{2}{*}{ Bleak } & Oct & 23 & 61 & 0 & - & - \\
\hline & Mar & 15 & 102 & 7 & $<1$ & 5 \\
\hline Herring & Mar & 9 & 191 & 0 & - & - \\
\hline Nine-spined stickleback & Mar & 1 & 40 & 0 & - & - \\
\hline \multirow[t]{2}{*}{ Perch } & Oct & 32 & 80 & 3 & $<1$ & 1 \\
\hline & Mar & 17 & 126 & 6 & $<1$ & 1 \\
\hline Roach & Mar & 5 & 115 & 0 & - & - \\
\hline Rudd & Oct & 2 & 40 & 0 & - & - \\
\hline Ruffe & Mar & 14 & 133 & 79 & 11 & 56 \\
\hline Three-spined stickleback & Mar & 17 & 61 & 0 & - & - \\
\hline
\end{tabular}

\section{Feeding experiment}

Eight weeks after infection, both prevalence of infection (i.e. no. of eels infected expressed as a percentage) and recovery of larvae (i.e. no. of worms recorded divided by no. of larvae fed to the eel expressed as a percentage) were higher among the eels kept at $20^{\circ} \mathrm{C}$ than among those kept at $10^{\circ} \mathrm{C}$ (Fig. 1). There was also a marked difference in the proportion of Anguillicola crassus in advanced stages of development. Only thirdand fourth-stage larvae were recovered from the eels kept at the lower water temperature, whereas preadult and adult parasites of both sexes were found in eels kept at $20^{\circ} \mathrm{C}$ (Fig. 2).

\section{Ultrastructural observations}

Larvae. The $\mathrm{L}_{3}$-larvae of Anguillicola crassus have a striated cuticle with lateral alae, i.e. thin cuticular projections or fins, running longitudinally on each side (Fig. 3). In the posterior tail end, however, the cuticle becomes punctuated. In the mouth region there are 2 lips or labia surrounded by a circle of 4 cephalic papillae situated dorso- and ventrolaterally as well as 2 lateral amphids, i.e. a pair of glandular sensory organs situated laterally in the cephalic region and opening through the cuticle. Three pairs of laterally situated deirids, 2 pairs pre-anal and 1 pair post-anal, are found at regular intervals. On the ventral side towards the tail, the anus is seen.

Adults. Our observations of the adults substantiate those made by Taraschewski et al. (1987). Adult worms have a rounded head. The indented mouth opening is rounded and surrounded by cephalic papillae and amphids as in the larvae. The posterior end of the male
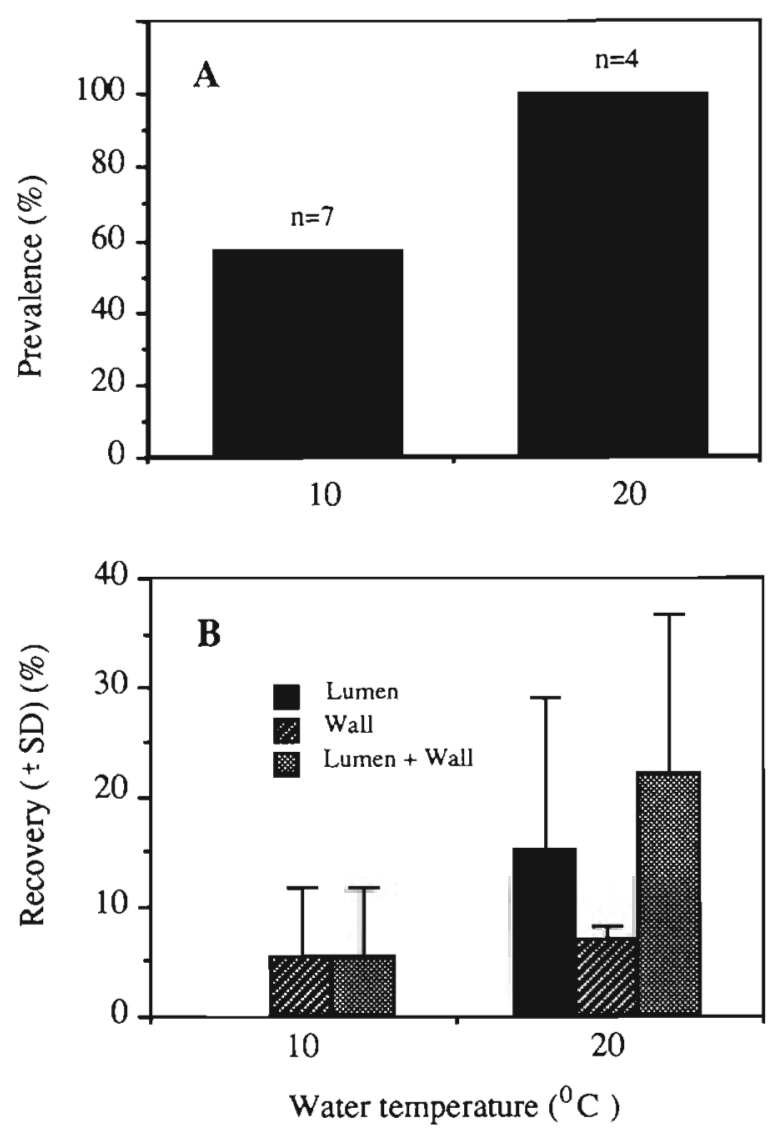

Fig. 1. Anguillicola crassus. Infection rate in eel orally exposed to a dose of $40 \mathrm{~L}_{3}$-larvae at a water temperature of 10 and $20^{\circ} \mathrm{C}$ shown as (A) prevalence of infection and (B) mean recovery, i.e. the percentage of the total no. of larvae that established themselves in the swimbladder wall and lumen.

Results are expressed as mean $\pm \mathrm{SD}$ for 4 to 7 fish

worm is equipped with a processus and 5 to 6 pairs of caudal papillae. The female is characterized by the vulva. 


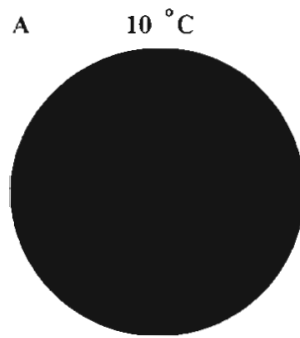

$n=17$

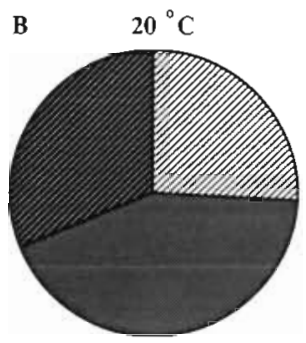

$n=35$
$\mathrm{L}_{3}-4$
Pre-adults

Adult females

7 Adult males
Fig. 2. Anguillicola crassus Relative proportion of developmental stages and sexes of parasite recovered in eels orally exposed to a dose of $40 \mathrm{~L}_{3}$-larvae at a water temperature of (A) $10^{\circ} \mathrm{C}$ and (B) $20^{\circ} \mathrm{C}$

\section{DISCUSSION}

Various copepods and ostracods have been observed to act as the intermediate host in the life cycle of the parasitic nematode, Anguillicola crassus (Petter et al. 1989, 1990, De Charleroy et al. 1990b, Kennedy \& Fitch 1990). Most fish species feed on planktonic crustaceans, at least during their early life stages. Consequently, eels may become infected by eating small specimens of such fish. In previous studies performed in Central Europe, infective $L_{3}$-larvae of $A$. crassus were found in several small freshwater fish, and it was suggested that they may serve as paratenic hosts (De Charleroy 1990b, Haenen \& van Banning 1990). It has also been demonstrated that, in artificially infected eels, A. crassus larvae obtained from different fish species migrated to the swimbladder and developed into adults (De Charleroy 1990b, Haenen \& van Banning 1991).

The present study centred on possible paratenic fish hosts for Anguillicola crassus in an area of the Baltic which is today the most heavily infected site in Sweden. As the area receives heated cooling water from a nuclear power station, effects of the ambient water temperature on the transmission and subsequent development of the parasite in the eel were also studied. The findings from this area differed significantly from findings from the inland fresh waters of Central Europe. Although we found ruffe to be infected, neither perch nor stickleback proved to be important paratenic hosts for $A$. crassus. Moreover, while previous studies have shown that, under laboratory conditions, A. crassus has a low degree of specificity to the copepods that host it (Thomas \& Ollevier 1989, Kennedy \& Fitch 1990), the only fish that became heavily infected in our investigation, the ruffe and
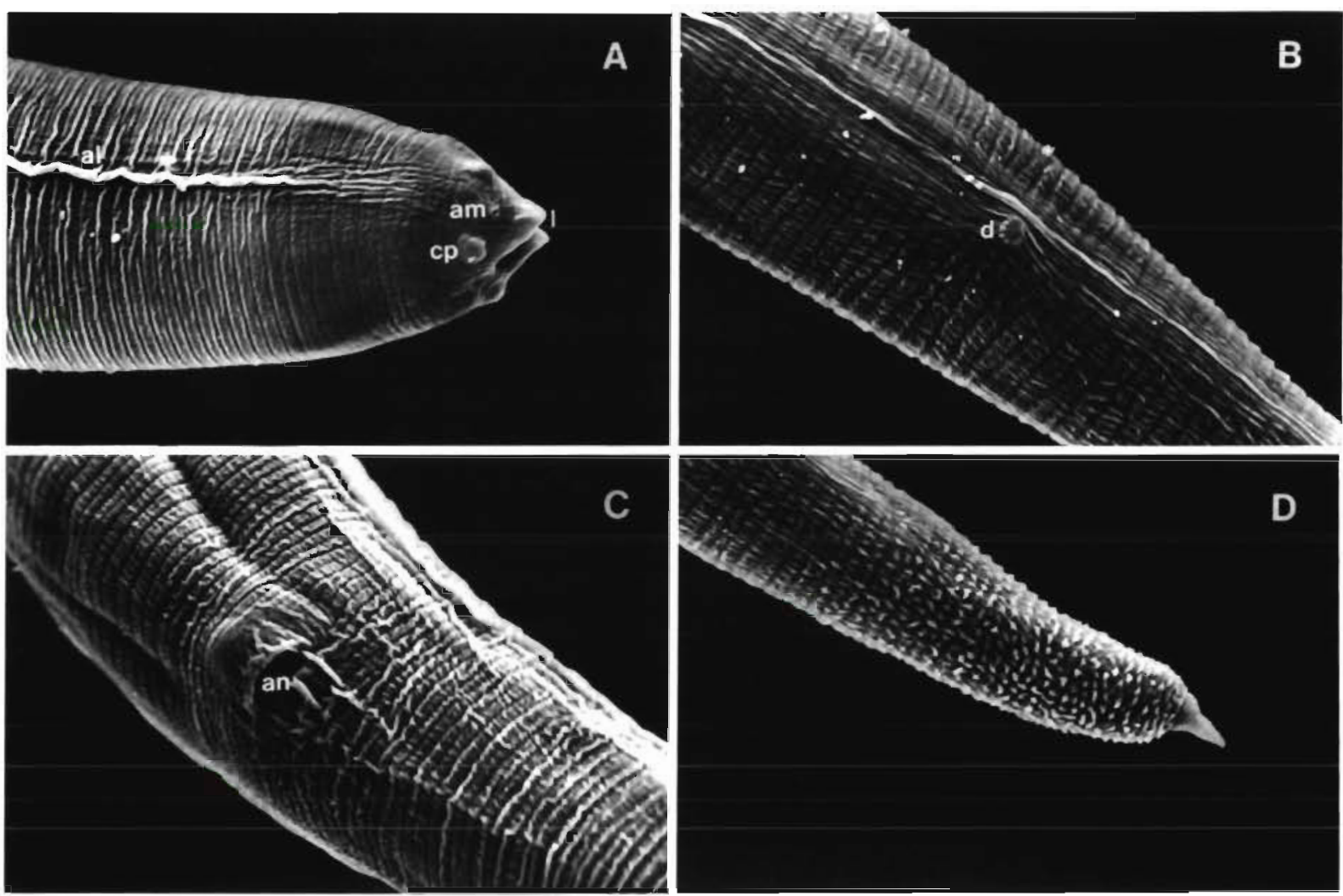

Fig. 3. Anguillicola crassus. SEM micrographs of $L_{3}$-larvae. (A) Anterior mouth region; (B) lateral view: (C) ventral view; (D) posterior tail end. al: ale; am: amphid; an: anus; cp: cephalic papilla; d: deirid; l: labia 
black goby, were benthic species. This result suggests that infection levels in the intermediate hosts may actually vary under natural conditions.

Numerous $\mathrm{L}_{3}$-larvae of Anguillicola crassus were recorded in the black goby. This species, unlike the ruffe, which was also found to be infected, is a marine species with a distribution down to $50 \mathrm{~m}$ in the Baltic, North Sea and Atlantic coasts of Europe (Muus \& Dahlstrom 1964). The viability of the $L_{2}$-larvae is highly reduced in marine biotopes and it has been suggested that the distribution of $A$. crassus is limited to freshand brackish waters (De Charleroy et al. 1989, Kennedy \& Fitch 1990). Infection of the black goby is therefore of particular interest to anguillicolosis research. It has been demonstrated that there is no loss of viability in $\mathrm{L}_{4}$-larvae and adults in infected eels maintained in sea water (Kennedy \& Fitch 1990). Consequently it is possible that infected black gobies carrying $\mathrm{L}_{3}$-larvae remain infective in the marine environment. If so, the black goby may serve as an important vector for $A$. crassus from estuaries to the sea.

The feeding experiment clearly revealed a positive relationship between parasite recovery and development and surrounding water temperature. However, it is not known if the larvae of Anguillicola crassus recovered from the eels kept at $10^{\circ} \mathrm{C}$ would have developed further if they had been kept for a longer period. In Sweden, infection with $A$. crassus has been observed to be concentrated to coastal areas of the Baltic receiving thermal discharges (Höglund et al. 1991). The present experiment supports the view that water temperature is an important factor for the infection dynamics of $A$. crassus.

In summary, it appears that in addition to freshwater fish species present in coastal waters, at least 1 marine species can also serve as a potential paratenic host for Anguillicola crassus. This extends the habitat conditions for transmission of infection. In addition, both transmission to and subsequent development of $A$. crassus in the eel were demonstrated to be facilitated by a moderately high water temperature. As Höglund et al. (in press) have suggested, raised water temperature per se could explain why the most heavily infected sites in Swedish coastal waters are areas affected by thermal discharges.

Acknowledgements. This research was supported by the Swedish Council for Forestry and Agricultural Research $(40.0322 / 90)$. Their support is gratefully acknowledged.

\section{LITERATURE CITED}

Belpaire, C., De Charleroy, D., Grisez, L., Ollevier, F. (1989a). Spreading mechanisms of the swimbladder parasite Anguillicola crassus in the European eel Anguilla anguilla and its distribution in Belgium and Europe. European
Inland Fishery Advisory Commission (EIFAC), Working Party on Eel, Porto

Belpaire, C., De Charleroy, D., Thomas, K., van Damme, P., Ollevier, F. (1989b). Effects of eel restocking on the distribution of the swimbladder nematode Anguillicola crassus in Flanders, Belgium. J. appl. Ichthyol. 5: 151-153

Canestri-Trotti, G. (1987). Occurrence of the nematode Anguillicola crassus Kuwahara, Niimi \& Itagaki, 1974 in eels from the Po delta, Italy. Bull. Eur. Ass. Fish Pathol. 7 : 109-111

De Charleroy, D., Cannaerts, V., Augustijn, H., Grisez, L., Boon, J. H. Ollevier, F. (1990a). An improved method for artificial infection of the European eel, Anguilla anguilla with Anguillicola crassus (Nematoda, Dracunculoidea). J. appl. Ichthyol. 6: 182-188

De Charleroy, D., Grisez, L., Thomas, K., Belpaire, C. (1987). Problems concerning the species determination, biology and diagnostical methods of Anguillicola, a swimbladder nematode in the European eel (Anguilla anguilla L.). European Inland Fishery Advisory Commission (EIFAC), Working Party on Eel, Bristol

De Charleroy, D., Thomas, K., Belpaire, C., Ollevier, F. (1990b). The life cycle of Anguillicola crassus. Dis. aquat. Org. 8: 77-84

Dekker, W., van Willigen, J. (1989). Short note on the distribution and abundance of Anguillicola in The Netherlands. J. appl. Ichthyol. 1: 46-47

Dupont, F., Petters, A. (1988). Anguillicola, un épizootie plurispécifique en Europe. Apparition d'Anguillicola crassa (Nematoda, Anguillicolidae) chez l'anguille européenne (Anguilla anguilla) en Camargue, Sud de la France. Bull. Fr. Pech. Pisci. 308: 38-41 (In French)

Egusa, S. (1979). Notes on the culture of the European eel (Anguilla anguilla L.) in Japanese eel-farming ponds. Rapp. P.-v. Réun. Cons. int. Explor Mer, 174: 51-58

Ghittino, C., Ghittino, P., De Matteo, M. M. (1989). Adjournment of Anguillicolosis, a frequent parasitic aerocystitis of eel. Riv. Ital. Acquacol. 24: 125-136

Haenen, O. L. M., van Banning, P. (1990). Detection of larvae of Anguillicola crassus (an eel swimbladder nematode) in freshwater fish species. Aquaculture 87: 103-109

Haenen, O. L. M., van Banning, P. (1991). Experimental transmission of Anguillicola crassus (Nematoda, Dracunculoidea) larvae from infected prey fish to the eel. Anguilla anguilla. Aquaculture 92: 115-119

Hellström, A., Ljungberg, O., Bornstein, S. (1988). Anguillicola, en ny ålparasit i Sverige. Svensk Veterinärtidning 40(4) : 211-213 (In Swedish)

Höglund, J., Andersson, J., Wickström, H., Reizenstein, M. (in press). The distribution of Anguillicola in Sweden - do thermal discharge areas serve as transmission foci for infected silver eels? Irish Fish. Invest.

Kennedy, C. R., Fitch, D. J. (1990). Colonization, larval survival and epidemiology of the nematode Anguillicola crassus, parasitic in the eel, Anguilla anguilla, in Britain. J. Fish Biol. 36: 117-131

Koops, H., Hartmann, F. (1989). Anguillicola-infestations in Germany and German eel imports. J. appl. Ichthyol. 1: $41-45$

Køie, M. (1988). Parasites in eels, Anguilla anguilla (L), from eutrophic Lake Esrum (Denmark). Acta Parasitol Pol. 33: 89-100

Muus, B. J., Dahlström, P. (1974). Collins guide to the sea fishes of Britain and North-Western Europe. Wm. Collins Sons and Co., Ltd., London

Neumann, W. (1985). Schwimmblasenparasit Anguillicola bei Aalen. Fischer und Teichwirt. 11: 322 (In German) 
Peters, G., Hartmann, F (1986). Anguillicola, a parasitic nematode of the swimbladder spreading among eel populations in Europe. Dis. aquat. Org. 1: 229-230

Petter, A. J., Cassone, J., Le Belle, N. (1990). Observations sur la biologie des premiers stades larvaires d'Anguillicola crassus, nématode parasite d'Anguille. Ann. Parasitol. Hum. Comp. 65: 28-31

Petter, A. J., Fontaine, Y A., Le Belle, N. (1989). Etude du dévelopment larvaire de Anguillicola crassus (Dracunculoidea, Nematoda) chez un cyclopidae de la région Parisienne. Ann. Parasitol. Hum. Comp. 64: 347-355

Székely, C., Láng, M., Csaba, G. (1991). First occurrence of Anguillicola crassus in Hungary. Bull. Eur. Fish Pathol. 11(4): $162-163$

Responsible Subject Editor: W. Körting, Hannover, Germany
Taraschewski, H., Moravec, F., Lamah, T., Anders, K. (1987). Distribution and morphology of two helminths recently introduced into European eel populations: Anguillicola crassus (Nematoda, Dracunculoidea) and Paratenuides ambiguus (Acanthocephala, Tenuisentidae). Dis. aquat Org. 3: 167-176

Thomas, K., Ollevier, F. (1989). Aspects of the life cycle of Anguillicola crassus. In: Barja, J. L., et al. (eds.) Proc. $4^{\text {th }}$ EAFP int. Conf. Santiago de Compestela, Spain, p. 74

van Banning, P., Haenen, O. L. M. (1989). Effects of the swimbladder nematode Anguillicola crassus in wild and farmed eel Anguilla anguilla. In: Perkins, F. O., Cheng, $\mathrm{T}$ C. (eds.) Pathology in Marine Science: Proc. $3^{\text {rd }}$ int. Coll. on Pathology in Marine Aquaculture. Academic Press, New York, p. 317-330

Manuscript first received: January 10,1992 Revised version accepted: June 1, 1992 